\title{
MICROSTRUCTURE AND MECHANICAL PROPERTIES OF HIGH- PURITY ALUMINUM DEFORMED WITH EQUAL-CHANNEL ANGULAR PRESSING
}

\author{
MIKROSTRUKTURA IN MEHANSKE LASTNOSTI ALUMINIJA \\ VISOKE ČISTOSTI, IZDELANEGA S POSTOPKOM ECAP
}

\author{
Lihua Li, Jin Wang, Songsong Gao \\ Qingdao Technological University, School of Mechanical Engineering, Qingdao 266033, China \\ jinwangqtech@163.com \\ Prejem rokopisa - received: 2018-04-05; sprejem za objavo - accepted for publication: 2018-06-14
}

doi:10.17222/mit.2018.068

\begin{abstract}
Annealed high-purity (99.99\%) aluminum was processed with equal-channel angular pressing (ECAP) via the Bc route making 1-8 passes at room temperature. The microstructure evolution of the materials processed at different pass numbers was observed and analyzed with EBSD; the influence of the ECAP-deformation pass number on the mechanical properties of high-purity aluminum was studied through mechanical-property tests. The result showed that the subgrain-boundary misorientation and the fraction of high-angle boundaries increased with an increased number of pressing passes. Dynamic recrystallization occurred and small equiaxed grains began to form after 4 passes; grains were refined to $4.0 \mu \mathrm{m}$ after 8 passes. The microhardness and tensile strength were obviously improved, while the elongation decreased. However, the tensile fracture remained a typical ductile fracture. The thermal stability of high-purity aluminum decreased after being annealed at $200{ }^{\circ} \mathrm{C}$.

Keywords: equal-channel angular pressing, high-purity aluminum, grain, mechanical properties
\end{abstract}

Avtorji prispevka so žarjen aluminij visoke čistosti $(99,99 \%)$ močno plastično deformirali s postopkom ECAP, to je z iztiskovanjem pod kotom $\mathrm{z}$ enakim vhodom in izhodom matrice (ECAP; angl.: Equal-Channel Angular Pressing) pri sobni temperaturi z od enim do osmimi prehodi skozi Bc. Mikrostrukturo deformiranih vzorcev so avtorji opazovali in analizirali z difrakcijo povratno sipanih elektronov (EBSD; angl.: Electron Back-Scattered Diffraction). S pomočjo testov mehanskih lastnosti so analizirali vpliv števila prehodov ECAP na deformacijo. Rezultati analiz so pokazali napačno orientacijo mej podzrn in naraščajoč delež visokokotnih mej zrn z naraščajočo deformacijo oz. naraščajočim številom prehodov; prišlo je do dinamične rekristalizacije in majhna enakoosna kristalna zrna so nastajala po 4 prehodih; kristalna zrna so se udrobila na $4.0 \mu \mathrm{m}$ po 8 prehodih. S stopnjo deformacije je očitno naraščala mikrotrdota in natezna trdnost vzorcev aluminija, medtem ko se je raztezek zmanjšal. Prelom po porušitvi vzorcev z nateznim preizkusom je ostal tipično duktilen. Termična stabilnost aluminija visoke čistosti se je poslabšala po žarjenju na $200^{\circ} \mathrm{C}$.

Ključne besede: postopek ECAP (iztiskovanje pod kotom z enakim vhodom in izhodom matrice), aluminij visoke čistosti, kristalna zrna, mehanske lastnosti

\section{INTRODUCTION}

Severe plastic deformation is an effective method for improving the mechanical properties of a pure metal without altering its chemical composition. ${ }^{1}$ Equalchannel angular pressing (ECAP) is one of the most rapidly developing and widely studied severe plastic deformation techniques. When a material is treated using ECAP, a large shear plastic deformation occurs at the corners. Samples can be pressed repeatedly at a relatively low pressure because the cross-sectional dimensions of the samples are almost unchanged after the deformation and a large effective strain is obtained due to the accumulating deformation volume. In this way, we can finally achieve the aims of the procedure: refinement of the grains, change in the microstructure of the material, and improvement of the mechanical properties. The ECAP technology is widely used for the preparation of pure metals, such as pure titanium, pure copper, pure magnesium and pure aluminum, because the operation is simple and pollution-free, and the ultrafine-grained bulk material prepared is compact.
Ma et al. reported that the grains of CP-Ti plates were obviously refined from the original value of 57.000 to $0.668 \mu \mathrm{m}$ and the microhardness was obviously improved after 8 passes of the ECAP method. ${ }^{2}$ Figueiredo et al. performed a 4-pass ECAP treatment on commercially pure titanium used for dental implants at room temperature. The results showed that the yield stress and the ultimate tensile stress increased to nearly the same levels as the titanium alloy. ${ }^{3}$ Hoseini et al. discussed the thermal stability and annealing behavior of ultrafinegrained commercially pure titanium after having been processed with ECAP via route $\mathrm{Bc}$ at $450{ }^{\circ} \mathrm{C}$, where the samples were rotated by $90^{\circ}$ with respect to the direction of the successive passes. ${ }^{4}$

Ding et al. ${ }^{5}$ studied the microstructure evolution, dislocation density and mechanical properties of pure copper processed via ECAP. They showed that the grains were refined, having a size of 5-10 $\mu \mathrm{m}$, dislocation density increased significantly, small-angle grain boundaries gradually transformed into large-angle grain boundaries, tensile strength was significantly improved, and plasticity was decreased. However, the tensile fracture was 
generally still manifested as plastic fracture. Guo et al. treated unidirectional solidification of pure copper processed with ECAP and found that the original grain boundaries were broken, while low-angle grain boundaries and high-angle grain boundaries occurred simultaneously with the increasing accumulated strain. ${ }^{6}$

Gan et al. ${ }^{7}$ heated pure magnesium to $623 \mathrm{~K}$ for an ECAP treatment. The grains were refined from $900 \mu \mathrm{m}$ to $50 \mu \mathrm{m}$, the tensile strength increased and the plasticity decreased. Mostaed et al. ${ }^{8}$ found that the microhardness and tensile strength of pure magnesium were not obviously increased after an ECAP treatment, while the elongation increased by $100 \%$.

Langdon performed an ECAP treatment on highpurity aluminum via a different route and found that $\mathrm{Bc}$ is the optimum processing route for achieving equiaxed grains. ${ }^{9}$ Tolaminejad et al. ${ }^{10}$ carried out an ECAP treatment on commercially pure aluminum via the $\mathrm{Bc}$ route. The experimental results showed that the hardness and yield strength decreased slightly, but the homogeneity of the material was improved by increasing the number of passes. Kawasaki et al. ${ }^{11}$ used a 12-pass ECAP treatment on high-purity aluminum via the $\mathrm{Bc}$ route. They showed that anomalously large grains were visible in the central region of a billet after more than 8 passes due to dynamic recovery and grain growth. Ivanov et al. ${ }^{12}$ found that the mechanical behavior of high-purity aluminum after an ECAP treatment exhibited high values of ultimate and yield stresses, and a relatively low elongation up to the failure. Yan et al. ${ }^{13}$ found that an increase in the strain rate could eliminate strain softening after high-purity aluminum was treated with ECAP.

High-purity aluminum has better conductivity, ductility, reflectivity and corrosion resistance than the original aluminum. It is widely applied in the electronics industry, automotive industry, aerospace and other fields. The strength and hardness of high-purity aluminum are low, but it is difficult to introduce the strengthening phase as engineering materials. The ECAP treatment of high-purity aluminum can cause a grain refinement and an improvement in the strength and hardness, while the plasticity remains in a reasonable range. There are not many researches focused on the preparation of ultrafine high-purity aluminum with ECAP. The purpose of the experiments reported here was to study the preparation of ultrafine crystal high-purity aluminum with ECAP. High-purity aluminum is treated with ECAP via the Bc route, and the influence of the ECAP-deformation pass number on the microstructure evolution and mechanical properties of materials are studied.

\section{MATERIALS AND EXPERIMENTAL METHODS}

The material used in this study was high-purity aluminum $(99.99 \%)$ and its chemical composition is shown in Table 1. Each sample was machined into a square blank with a size of $15 \mathrm{~mm} \times 15 \mathrm{~mm} \times 90 \mathrm{~mm}$ and annealed. The annealing process was carried out at $350{ }^{\circ} \mathrm{C}$ for $2 \mathrm{~h}$ in a furnace and then slowly cooled down. The pressing experiment was carried out on a hydraulic press (YL32-63, Nantong Liyou hydraulic press equipment Co., Ltd.). A sample was pressed 8 times via the Bc route, i.e., the sample pressed in the previous pass was rotated by $90^{\circ}$ with respect to the direction of the next pass, using a self-designed ECAP longitudinal split die with an inside angle of $90^{\circ}$ and an outside angle of $20^{\circ}$.

Table 1: Chemical composition of A199.99 (w/\%)

\begin{tabular}{|c|c|c|c|c|c|c|}
\hline $\begin{array}{c}\text { Chemical } \\
\text { composition }\end{array}$ & $\mathrm{Al}$ & $\mathrm{Fe}$ & $\mathrm{Si}$ & $\mathrm{Cu}$ & $\mathrm{Zn}$ & $\mathrm{Ti}$ \\
\hline$\%$ & 99.99 & 0.0019 & 0.0020 & 0.0035 & 0.0004 & 0.0001 \\
\hline
\end{tabular}

Before the pressing, a mixture of graphite powder and industrial grease was applied onto the surface of the channel and the samples. The cross-sectional dimensions of a specimen were increased slightly and the head was warped after being pressed. The samples were milled a little to ensure that the next pass was carried out smoothly.

After the ECAP experiments, the microstructure and mechanical properties of the main deformation region of the samples were studied.

The microstructure of high-purity aluminum was observed with EBSD, orientation imaging microscopy was used and grain orientation distribution was obtained.

A microhardness test was carried out at 6 points throughout the cross-section of each sample using an FM-700 digital microhardness tester. The load was $50 \mathrm{~g}$ and the loading time was $15 \mathrm{~s}$. The average Vickershardness value was taken as the final figure.

Annealing treatment was carried out on the specimens after the deformation using an SXQF-5-12 programmable atmospheric protection chamber furnace to analyze the thermal stability of the high-purity aluminum after the ECAP deformation achieved with different numbers of passes.

Two kinds of annealing treatments were adopted, that is, heat preservation at $100{ }^{\circ} \mathrm{C}$ for $1 \mathrm{~h}$ and heat preservation at $200{ }^{\circ} \mathrm{C}$ for $1 \mathrm{~h}$. The microhardness test was carried out for the treated samples. The Vickers hardness was measured at 6 points on the upper surface of each sample, and the average was taken as the final figure.

A tensile test was performed using a SHIMADZUAG-IS-250KN electronic universal testing machine. Tensile specimens were cut along the extrusion direction with a wire. The values for the tensile strength and elongation of the specimens were obtained after each deformation.

A Hitachi S-3500N scanning electron microscope was used to observe the fracture surfaces of the specimens after the deformation. The influence of different numbers of passes on the tensile fracture morphology 

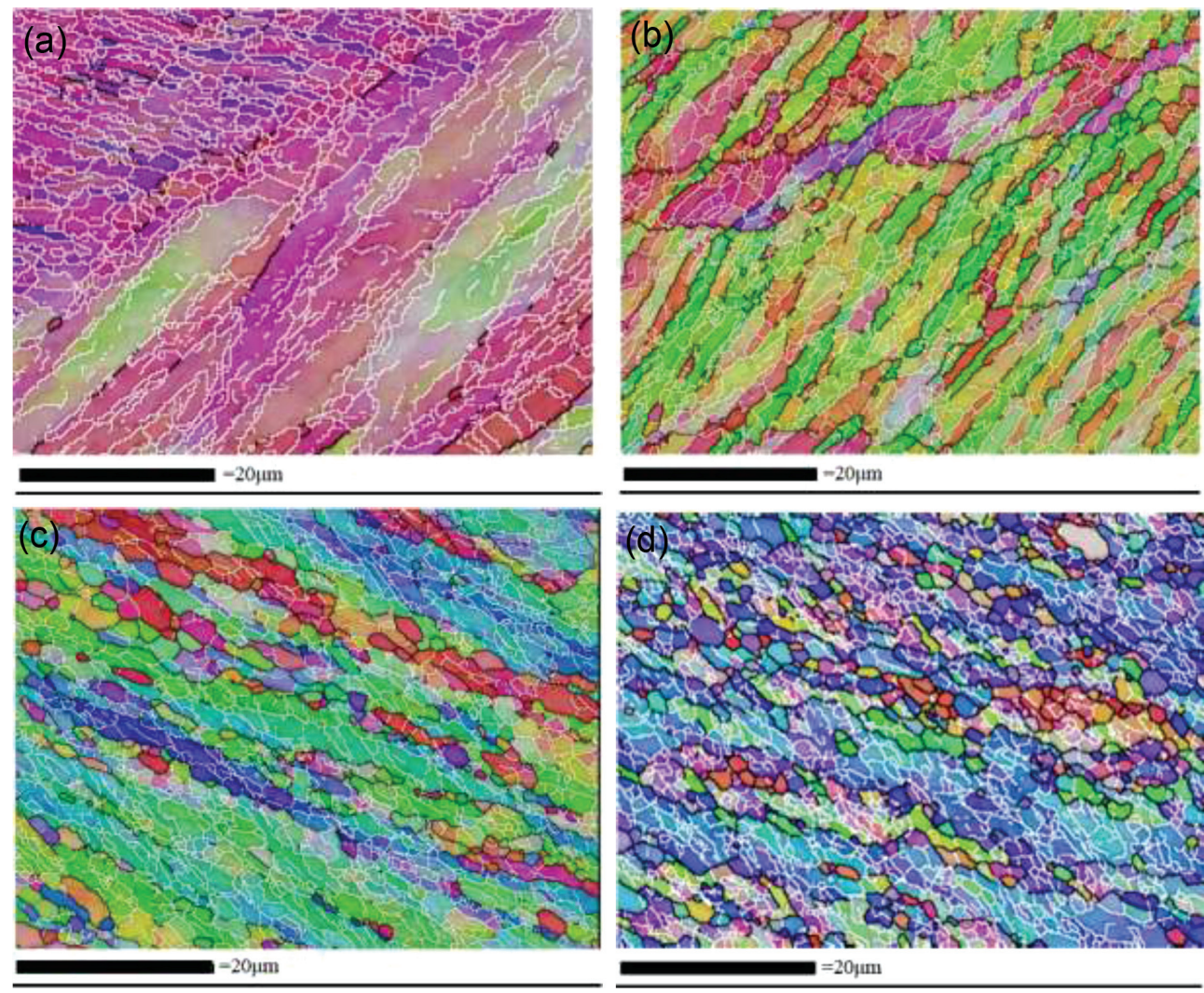

Figure 1: OIM photographs of high-purity aluminum samples: a) after 1st pass, b) after 2nd pass, c) after 4th pass, d) after 8th pass

was analyzed, and the variation in the elongation was verified.

\section{RESULTS AND DISCUSSION}

After the first ECAP treatment, the side surfaces of the samples were quite rough, but there were no cracks or holes. Obvious cracks occurred after the fifth pass. The cracks increased with the subsequent pressing passes, but were mainly distributed on the end parts. The mechanical properties of the samples were studied in their middle parts.

\subsection{Microstructure observation}

As the annealed high-purity-aluminum grains were very large, only 1-2 grains could be observed in the $4 \mathrm{~mm} \times 4 \mathrm{~mm}$ test field of orientation imaging microscopy (OIM). Figures 1 and $\mathbf{2}$ show the OIM images and grain-orientation distribution obtained with EBSD after the 1st, 2nd, 4th and 8th deformation pass, respectively.
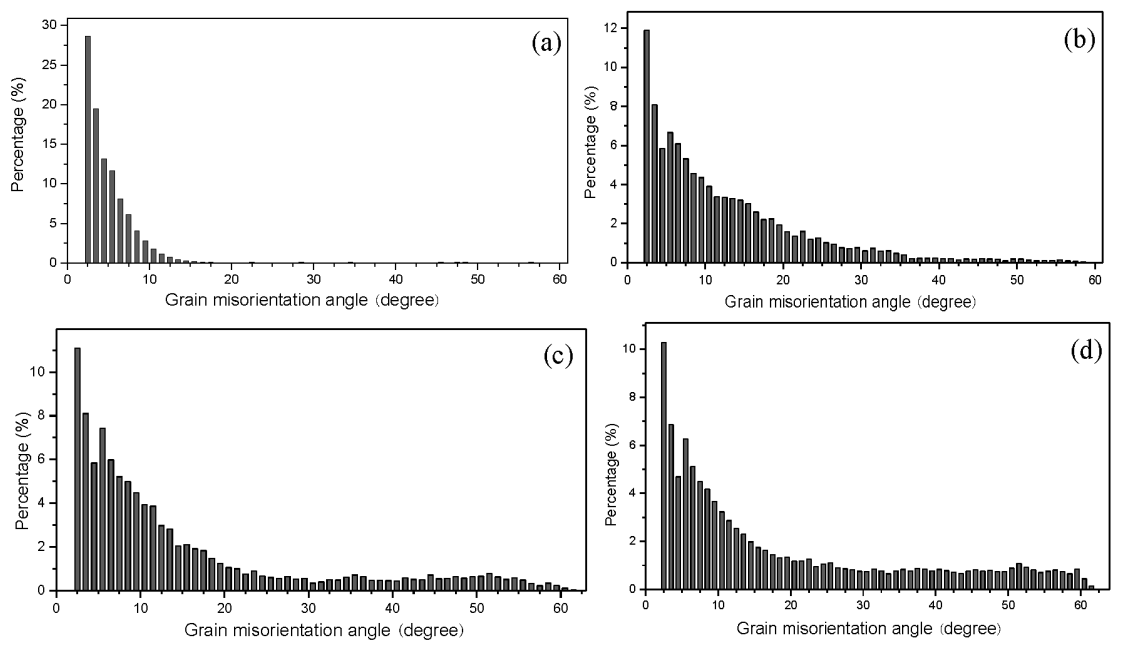

Figure 2: Grain-orientation distribution of high-purity aluminum samples: a) after 1st pass, b) after 2nd pass, c) after 4th pass, d) after 8th pass 
In Figure 1a, the initial grains are broken along the shear direction in the test field after the 1 st pass. Most subgrains are similar in color, which means that the subgrain-orientation difference is small. After the 2nd pass, the elongated subgrains are further sheared due to the $90^{\circ}$ rotation in the pressing direction. The difference in the subgrain orientation increases, and the high-angle grain boundaries begin to appear, as shown in Figures $\mathbf{1 b}$ and $\mathbf{2 b}$. After the 4th pass, fine equiaxed grains were achieved because of dynamic recrystallization. ${ }^{14}$ The microstructure consisted of elongated subgrains and equiaxed grains, and the amount of large-angle grain boundaries increased to $30 \%$ as shown in Figures 1c and 2c. After the deformation of the 8th pass, the number of equiaxed grains obviously increased and the distribution was more uniform according to Figure 1d. The grains were effectively refined. The average grain size was $4.0 \mu \mathrm{m}$. The amount of large-angle grains was further increased, as seen in Figure 2d.

\subsection{Mechanical properties}

\subsubsection{Microhardness}

Figure 3 shows the relationship between the Vickers hardness and pass number, where the abscissa value 0 represents the original annealing sample without the ECAP treatment. It can be seen that the hardness of the high-purity aluminum sample increased monotonously with the increase in the number of ECAP passes. After the 3rd pass, the increase in the hardness slowed down. After the 8th pass, the hardness of the sample increased from 44.9 to $65.7 \mathrm{HV}$, which was $46.3 \%$ higher than for the original sample.

After ECAP, a high-purity aluminum sample underwent a nearly pure shear deformation. The grains were elongated, the dislocation density increased sharply, and the hardness increased dramatically. With the increase in the number of ECAP passes, the shear strain accumulated and increased. The dislocation increase was accompanied by dislocation annihilation, which reduced the increase rate for the dislocation density ${ }^{15}$ and thus the hardness of the material might have slowly increased.

\subsubsection{Thermal stability}

Figure 4 shows the microhardness curves of highpurity aluminum samples after different deformation passes, without annealing, and after annealing at $100{ }^{\circ} \mathrm{C}$ and $200{ }^{\circ} \mathrm{C}$. The microhardness-curve trend of the sample annealed at $100{ }^{\circ} \mathrm{C}$ is the same as that of the non-annealed sample, and the value did not drop significantly. High-purity aluminum after the ECAP deformation performed during different passes had a good thermal stability at $100{ }^{\circ} \mathrm{C}$.

The microhardness curves show different changes before and after the 4 passes after the annealing at $200{ }^{\circ} \mathrm{C}$. Compared with the non-annealed microhardness curve before the 4 passes, the trend of the curve after annealing is basically the same, and the microhardness value does not decrease obviously. The value decreased after the 1st pass was the minimum, which was $3.3 \%$, while the value after the 4 th pass was the maximum, which was $9.9 \%$. High-purity aluminum after only 4 passes of the ECAP deformation still had a good thermal stability at $200{ }^{\circ} \mathrm{C}$. With the increase in the number of deformation passes, the hardness curve after annealing showed a significant decrease compared with that without annealing. Among them, the decreased value after the 8th pass was the maximum, which was $26.2 \%$. The thermal stability of high-purity aluminum was on a decrease.

The phenomenon above can be explained as follows: the deformation degree of high-purity aluminum increased with the increasing number of ECAP passes, and the deformation-stored energy in the metal continued to accumulate; the driving force of recrystallization

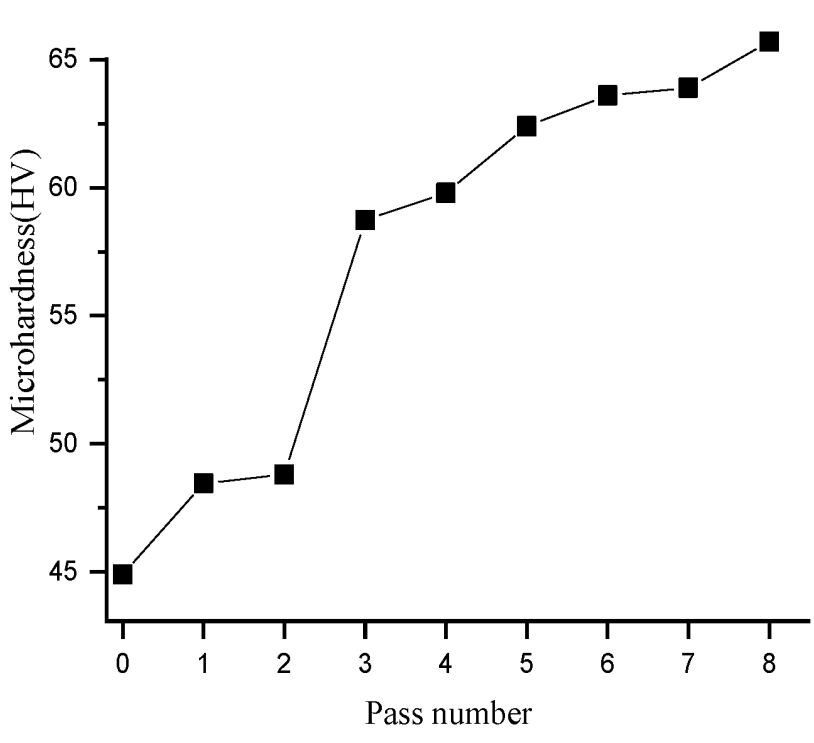

Figure 3: Curve of microhardness vs. pass number

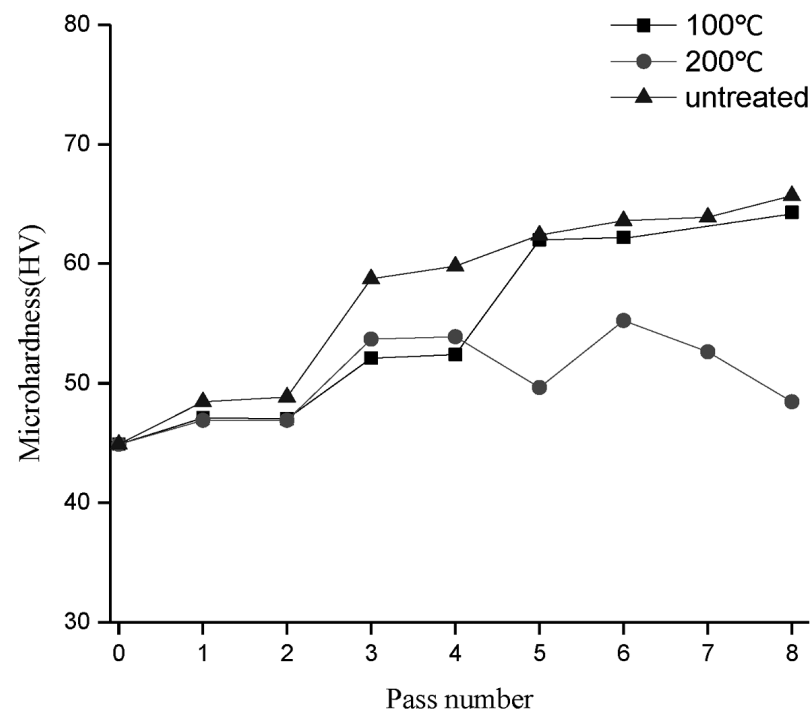

Figure 4: Curves of microhardness vs. pass number under different retreatment temperatures 


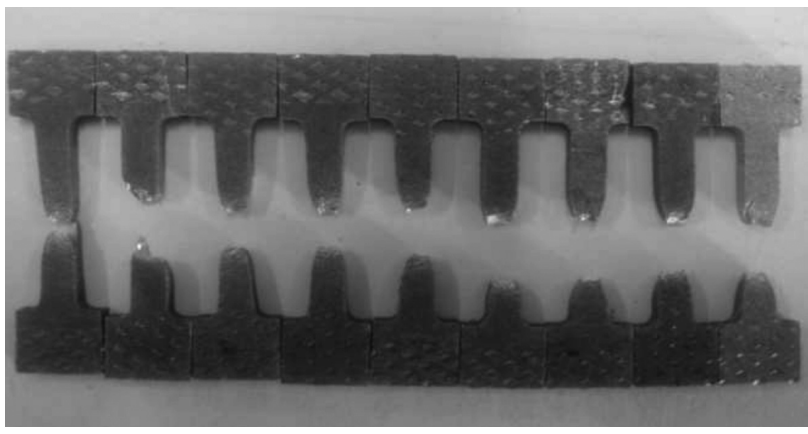

Figure 5: Tensile-test samples

increased, resulting in a decrease of the recrystallization temperature. ${ }^{16}$

For the high-purity aluminum samples after no more than 4 passes of the ECAP deformation, the internal deformation-stored energy was not large enough to make the recrystallization temperature drop to $200{ }^{\circ} \mathrm{C}$. Recrystallization could not occur, but only a recovery occurred during the annealing process at $200{ }^{\circ} \mathrm{C}$. The recovery caused a decrease in point defects and a reduction in dislocation density, thus resulting in a slight decrease in the material hardness.

From the 5th pass onwards, the internal deformation-stored energy was large enough. The recrystallization temperature was further reduced below $200{ }^{\circ} \mathrm{C}$. In the process of annealing, recrystallization occurred in addition to the recovery, which induced a significant reduction in the dislocation density. The hardness of the material decreased obviously. However, after the 8th pass of the ECAP deformation, the internal deformationstored energy was still not large enough to make the recrystallization temperature drop below $100{ }^{\circ} \mathrm{C}$. No recrystallization occurred during the annealing at $100{ }^{\circ} \mathrm{C}$, only a recovery occurred. This made the material hardness decrease slightly.

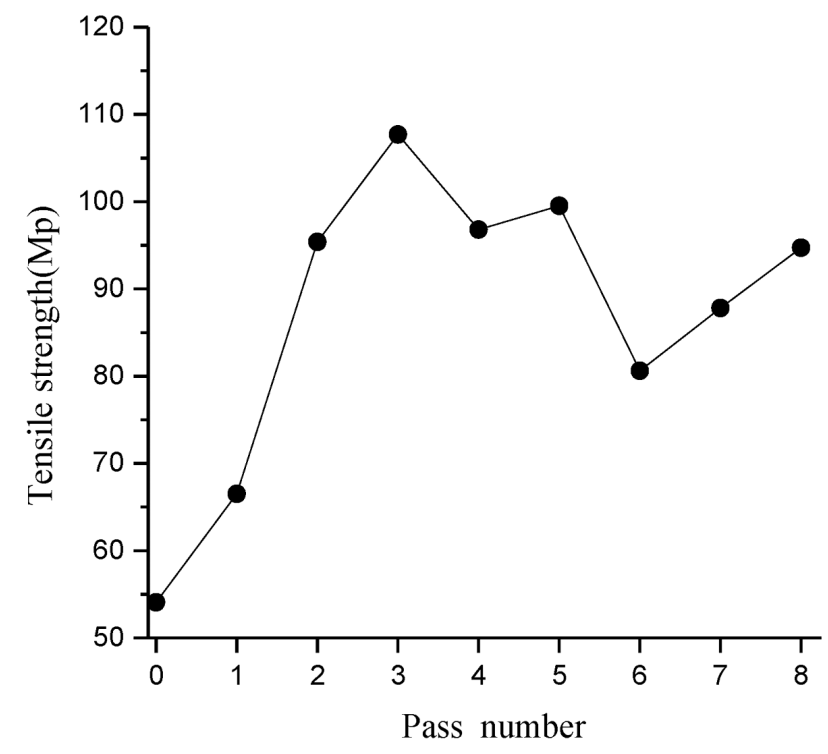

Figure 6: Curve of tensile strength vs. pass number

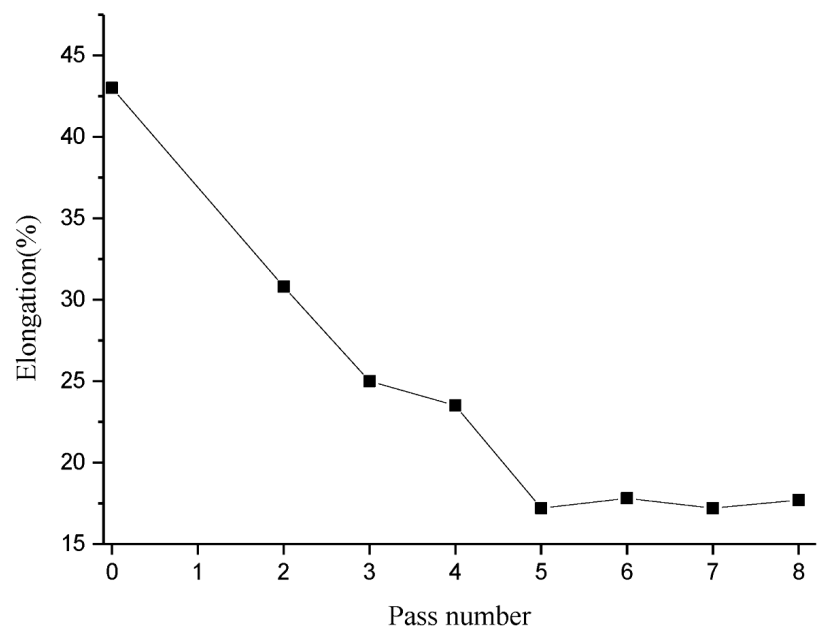

Figure 7: Curve of elongation vs. pass number

\subsubsection{Tensile strength}

Figure 5 shows high-purity aluminum samples processed at different deformation passes after the tensile test. Figure 6 shows the relationship between the tensile strength and the pass number. After the ECAP deformation, the tensile strength increased rapidly with the increasing pass number. After the 3rd pass, the tensile strength increased from $54 \mathrm{MPa}$ to $108 \mathrm{MPa}$. This might have been due to the fact that the high-purity aluminum samples underwent the near-pure shear deformation due to ECAP, and the dislocation density increased dramatically, resulting in the material hardening and the tensile strength increasing with the number of deformation passes. With the increase in the deformation passes, dynamic recrystallization occurred in the material and the material softened. Both work hardening and material softening caused by dynamic recrystallization affected the samples. After the 4th pass, the material was less affected by work hardening than dynamic recrystallization, so the tensile strength decreased. The impact of both the hardening and softening mechanisms was also the reason why the tensile strength fluctuated after the 4 th pass.

\subsubsection{Elongation}

Figure 7 shows the relationship between the elongation and pass number. For the first 5 passes, the elongation of high-purity aluminum samples decreased rapidly with deformation passes, from $43 \%$ to $17.2 \%$. Between the 5th pass and the 8the pass, the elongation tended to be stable exhibiting a lower fluctuation, that is, the plasticity tended to be stable. The elongation-variation tendency of high-purity aluminum samples was opposite to that of the hardness.

\subsection{Tensile-fracture-morphology analysis}

Figure 8 shows the tensile-fracture morphology of the samples after different numbers of passes. On the 

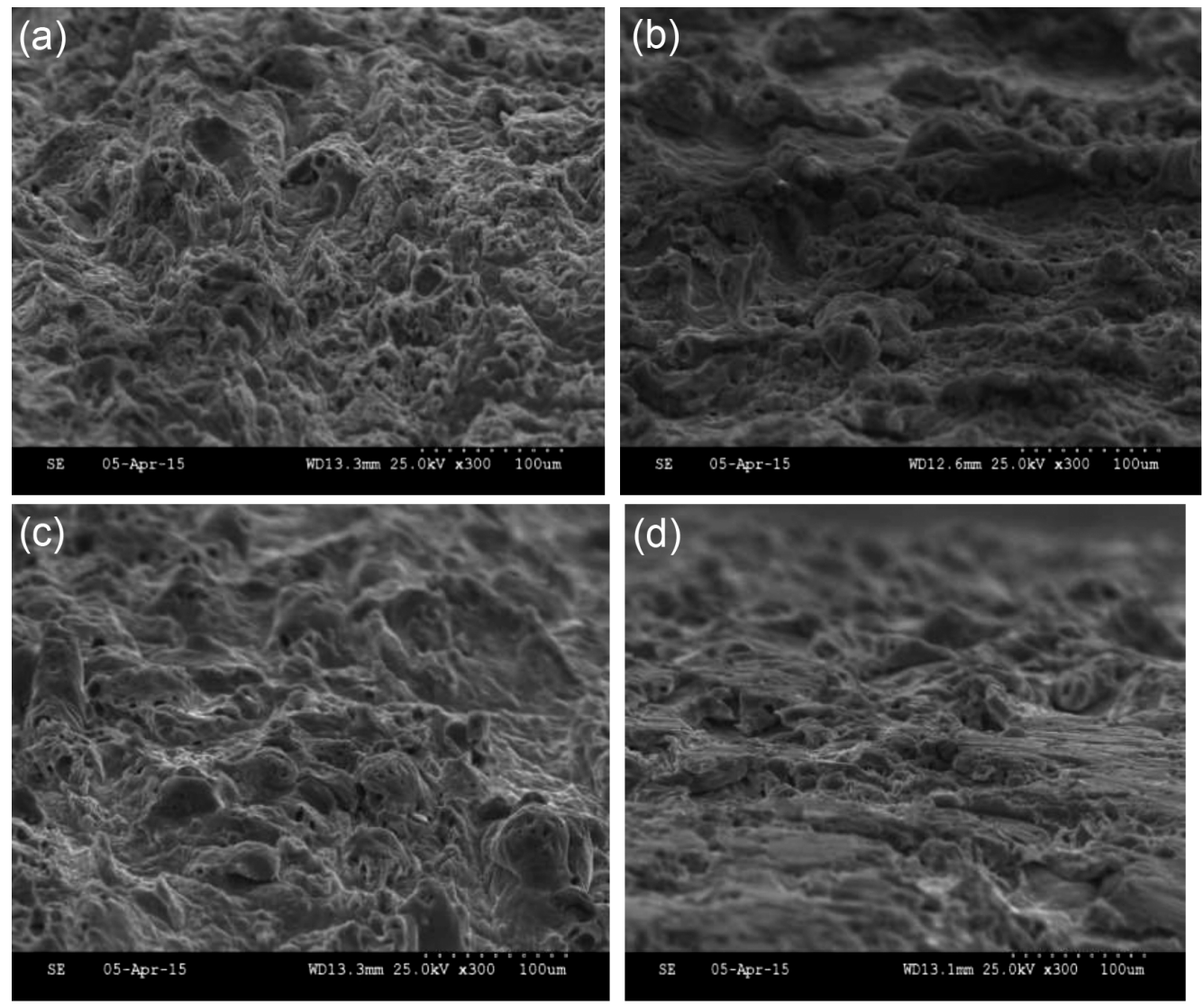

Figure 8: Sample morphologies of tensile fractures after different passes: a) original, b) 1, c) 5, d) 7

SEM images, there are obvious dimples and tear ridges on the tensile fracture of the samples after each deformation pass. Dimples are deep and distributed throughout the fracture. It is a typical ductile fracture. When compared, the dimples are most fine and uniform, while the tear ridges of the annealed samples are protruding and obvious; after the first 5 passes, the dimples on the fracture are a little less fine and uniform; in the period between the 6th and 8th pass, the dimples gradually become shallow and unevenly distributed and the tear ridges gradually become flat. That is, with the increase in the pass number, the dimples and tear ridges on the tensile fracture become gentle, and the variations are consistent with that of the elongation.

\section{CONCLUSIONS}

According to the analyses of the microstructures, the mechanical properties and the tensile fractures of the high-purity aluminum samples that were subjected to different numbers of the ECAP treatment passes, the following conclusions can be drawn:

1) The difference in the orientation among the subgrains increased and the proportion of large-angle grain boundaries was increasing continuously with the increasing pass number. After the 4th pass, dynamic recrystallization took place and fine equiaxed grains appeared. After the 8th pass, the grains were more equiaxed and evenly distributed. The grains were effectively refined with an average grain size of $4.0 \mu \mathrm{m}$.

2) The microhardness of the high-purity aluminum samples increased monotonically with the pass number. It increased rapidly after the 3rd pass and more slowly after further passes. The elongation variation tendency was opposite to that of the microhardness.

3) High-purity aluminum after the ECAP deformation carried out at different pass numbers had a good thermal stability at $100{ }^{\circ} \mathrm{C}$. At $200{ }^{\circ} \mathrm{C}$, the thermal stability of the samples after the first 4 deformation passes remained good. After the 8th pass, recrystallization occurred and the thermal stability decreased.

4) After the ECAP deformation, the tensile strength increased rapidly and then fluctuated.

5) The tensile fracture was a typical ductile fracture after exposure to different numbers of deformation passes. However, with the increase in the pass number, the dimples and tear ridges on the fracture became gentle and the variations were consistent with that of the elongation.

\section{Acknowledgment}

This work was supported by the National Natural Science Foundation of China under Grant No. 51775289. 


\section{REFERENCES}

${ }^{1}$ M. Ebrahimi, C. Gode, Severely deformed copper by equal channel angular pressing, Prog. Nat. Sci., 27 (2017), 244-250, doi:10.1016/j.pnsc.2017.03.002

${ }^{2}$ W. Ma, X. Yang, X. Zhao, D. Xie, Q. Wang, Microstructure and properties of CP-Ti plates processed by ECAP at room temperature, Chin. J. Rare Metals, 39 (2015), 1071-1075, in Chinese, doi:10.13373/j.cnki.cjrm.2015.12.002

${ }^{3}$ R. B. Figueiredo, E. R. D. C. Barbosa, X. Zhao, X. Yang, X. Liu, Improving the fatigue behavior of dental implants through processing commercial purity titanium by equal-channel angular pressing, Mat. Sci. Eng. A, 619 (2014), 312-318, doi:10.1016/j.msea.2014.09.099

${ }^{4}$ M. Hoseini, M. H. Pourian, F. Bridier, H. Vali, J. A. Szpunar, P. Bocher, Thermal stability and annealing behaviour of ultrafine grained commercially pure titanium, Mat. Sci. Eng. A, 532 (2012), 58-63, doi:10.1016/j.msea.2011.10.062

${ }^{5}$ Y. Ding, B. Liu, T. Guo, Y. Hu, H. Li, J. Zhao, Dislocation density variation and mechanical properties of pure copper via equal channel angular pressing, Chin. J. Nonf. Metals, 24 (2014), 2057-2064, in Chinese, doi:10.19476/j.ysxb.1004.0609.2014.08.017

${ }^{6}$ T. Guo, Y. Ding, X. Yuan, Y. Hu, Microstructure and orientation evolution of unidirectional solidification pure copper during ECAP, Rare Metal Mat. Eng., 40 (2011), 171-175

${ }^{7}$ W. Gan, M. Zheng, H. Chang, X. Wang, X. Qiao, K. Wu, B. Schwebke, H.-G. Brokmeier, Microstructure and tensile property of the ECAPed pure magnesium, J. Alloys Compd., 470 (2009), 256-262, doi:10.1016/j.jallcom.2008.02.030

${ }^{8}$ E. Mostaed, M. Vedani, M. Hashempour, M. Bestetti, Influence of ECAP process on mechanical and corrosion properties of pure $\mathrm{Mg}$ and ZK60 magnesium alloy for biodegradable stent applications,
Biomatter, 4 (2014), e28283, PMID: 24561829, doi:10.4161/ biom. 28283

${ }^{9}$ T. G. Langdon, The principles of grain refinement in equal-channel angular pressing, Mat. Sci. Eng. A, 462 (2007), 3-11, doi:10.1016/ j.msea.2006.02.473

${ }^{10}$ B. Tolaminejad, M. M. Hoseini-Athar, An investigation of microstructure and mechanical properties during ECAE of commercially pure aluminum, Mat. Sci. Eng. A, 670 (2016), 146-152, doi:10.1016/j.msea.2016.05.118

${ }^{11}$ M. Kawasaki, Z. Horita, T. G. Langdon, Microstructural evolution in high purity aluminum processed by ECAP, Mat. Sci. Eng. A, 524 (2009), 143-150, doi:10.1016/j.msea.2009.06.032

${ }^{12}$ K. V. Ivanov, E. V. Naydenkin, Tensile behavior and deformation mechanisms of ultrafine-grained aluminum processed using equalchannel angular pressing, Mat. Sci. Eng. A, 606 (2014), 313-321, doi:10.1016/j.msea.2014.03.114

${ }^{13}$ Y. Yan, Q. Yue, L. Chen, X. Li, Strain rate-dependent high temperature compressive deformation characteristics of ultrafine-grained pure aluminum produced by ECAP, Trans. Nonf. Met. Soc. Chin., 26 (2016), 966-973, doi:10.1016/S1003-6326(16)64193-6

${ }^{14}$ W. Skrotzki, N. Scheerbaum, C.-G. Oertel, H.-G. Brokmeier, S. Suwas, L. S. Toth, Recrystallization of high-purity aluminium during equal channel angular pressing, Acta Mat., 55 (2007), 2211-2218, doi:10.1016/j.actamat.2006.08.018

${ }^{15}$ B. Tolaminejad, K. Dehghani, Microstructural characterization and mechanical properties of nanostructured AA1070 aluminum after equal channel angular extrusion, Mater. Des., 34 (2012), 285-292, doi:10.1016/j.matdes.2011.08.003

${ }^{16}$ W. Q. Cao, A. Godfrey, W. Liu, Q. Liu, EBSP study of the annealing behavior of aluminum deformed by equal channel angular processing, Mat. Sci. Eng. A, 360 (2003), 420-425, doi:10.1016/S09215093(03)00508-2 